\title{
ALTITUDINAL GENETIC VARIATION AMONG Pinus pseudostrobus POPULATIONS FROM MICHOACÁN, MÉXICO. TWO LOCATION SHADEHOUSE TEST RESULTS
}

\author{
VARIACIÓN GENÉTICA ALTITUDINAL ENTRE POBLACIONES DE Pinus pseudostrobus DE \\ MICHOACÁN, MÉXICO. RESULTADOS DE ENSAYO EN CASAS DE SOMBRA EN DOS LOCALIDADES
}

\author{
Cuauhtémoc Sáenz-Romero ${ }^{1 *}$, Gerald E. Rehfeldt ${ }^{2}$, José Carmen Soto-Correa ${ }^{1}$, Selene Aguilar-Aguilar ${ }^{3,5}$, \\ Verónica Zamarripa-Morales ${ }^{3}$ and Javier López-Upton ${ }^{4}$
}

\begin{abstract}
${ }^{1}$ Instituto de Investigaciones Agropecuarias y Forestales, Universidad Michoacana de San Nicolás de Hidalgo (IIAF-UMSNH). Km 9.5 Carretera MoreliaZinapécuaro. 58880, Tarímbaro, Michoacán, México. ${ }^{2}$ Forestry Sciences Laboratory, Mountain Research Station, USDA Forest Service. 1221 S. Main, Moscow, Idaho 83843, USA. ${ }^{3}$ Facultad de Biología, Universidad Michoacana de San Nicolás de Hidalgo. Av. Francisco J. Mújica s/n, Col. Felícitas del Río. Morelia, Michoacán, México. ${ }^{4}$ Forestal, Colegio de Postgraduados Campus Montecillo. Km. 36.5 Carr. México-Texcoco. 56230 Montecillo, Texcoco, Estado de México, México. ${ }^{5}$ Present address: Instituto de Ciencias Agrícolas, Universidad Autónoma de Baja California (ICA-UABC). Carretera a Delta s/n. 21705 , Ejido Nuevo León, Baja California, México.
\end{abstract}

${ }^{*}$ Corresponding autor (csaenzromero@gmail.com)

\section{SUMMARY}

Pinus pseudostrobus Lindl. is the forest species most important economically in the state of Michoacán, at central-west México. We investigated genetic variation among $P$. pseudostrobus populations along an altitudinal gradient in the native indian community of Nuevo San Juan Parangaricutiro, Michoacán, México. Cones were collected from eight populations at $100 \mathrm{~m}$ of altitudinal intervals between $2200 \mathrm{~m}$ and $2900 \mathrm{~m}$. Seedlings were grown for approximately two years in two shadehouse environments at Morelia, Michoacán, México and at Moscow, Idaho, USA. Total height was periodically measured during the second growing season to estimate a series of growth indexes for both locations, and dry weights were obtained only for the Morelia test. For the Moscow test there were significant differences $(P<0.05)$ among populations for cessation of growth, duration of the growth period, and final height. For the Morelia tests there were differences among populations for foliage, shoot and total dry weight $(P<0.025)$, and significant differences for stem dry weight at $\mathbf{P}=\mathbf{0 . 0 5 5}$ level. There was a strong altitudinal cline for dry weight variables, with seedlings originated from populations from the lowest altitudes having more biomass $\left(r^{2}=0.80, P=0.003\right)$. Populations separated altitudinally by about $295 \mathrm{~m}$ are likely to be genetically different. We suggest delineation of three altitudinal seed zones (Zone I: $2100 \mathrm{~m}$ to $2400 \mathrm{~m}$; Zone II: $2400 \mathrm{~m}$ to $2700 \mathrm{~m}$; Zone III: $2700 \mathrm{~m}$ to $3000 \mathrm{~m}$ ), that can be translated into climatic zones delimited according to mean annual temperatures or by degree days $>5^{\circ} \mathrm{C}$. To accommodate climate change we suggest implementing assisted migration programs by transferring populations $300 \mathrm{~m}$ upwards to maintain adaptiveness of populations for future climates.

Index words: Pinus pseudostrobus, altitudinal genetic variation, altitudinal seed zoning, assisted migration, climatic change.

\section{RESUMEN}

Pinus pseudostrobus Lindl. es la especie forestal económicamente más importante en el Estado de Michoacán, al centro-oeste de México. Se investigó la variación genética entre poblaciones de $P$. pseudostrobus a lo largo de un gradiente altitudinal en los bosques de la comunidad indígena de Nuevo San Juan Parangaricutiro, Michoacán, México. Se colectaron conos de ocho poblaciones a intervalos altitudinales de $100 \mathrm{~m}$, entre $2200 \mathrm{~m}$ y $2900 \mathrm{~m}$. Las plantas se crecieron por aproximadamente dos años en dos diferentes ambientes de casas de sombra: en Morelia, Michoacán, México y en Moscow, Idaho, USA. La altura total se midió periódicamente durante la segunda estación de crecimiento para estimar una serie de índices de crecimiento para ambas localidades, y en Morelia se estimaron variables de peso seco. En el ensayo de Moscow hubo diferencias significativas $(P<0.05)$ entre poblaciones para terminación, duración del período de crecimiento y para altura final. En el ensayo de Morelia hubo diferencias significativas entre poblaciones para peso seco de follaje, parte aérea y total $(\mathrm{P}<\mathbf{0 . 0 2 5})$, y para peso seco del tallo al nivel de $\mathbf{P}=\mathbf{0 . 0 5 5}$. Existió un fuerte patrón clinal altitudinal para las variables de peso seco, en donde las plantas originadas de poblaciones de la menor altitud tuvieron mayores valores de biomasa $\left(\mathrm{r}^{2}=0.80, \mathrm{P}\right.$ $=0.003$ ). Es probable que las poblaciones separadas por $295 \mathrm{~m}$ de diferencia altitudinal sean genéticamente diferentes. Aquí se propone la delimitación de tres zonas altitudinales (Zona I: $2100 \mathrm{~m}$ a $2400 \mathrm{~m}$; Zona II: $2400 \mathrm{~m}$ a $2700 \mathrm{~m}$; Zona III: $2700 \mathrm{~m}$ a $3000 \mathrm{~m}$ ), que se pueden convertir en zonas climáticas delimitadas por temperatura media anual o grados día $>5{ }^{\circ} \mathrm{C}$. Para dar cabida al cambio climático, se sugiere implementar programas de migración asistida para transferir poblaciones hacia arriba $(300 \mathrm{~m})$, como una medida de adaptación de las poblaciones a los climas futuros. 
Palabras clave: Pinus pseudostrobus, cambio climático, migración asistida, variación genética altitudinal, zonificación altitudinal de semillas.

\section{INTRODUCTION}

Pinus pseudostrobus Lindl. is a pine tree that is distributed mostly in the pine and pine-oak forests of México. It commonly grows on volcanic soils and in temperate to warm-temperate climates with annual precipitations between 800 and $1500 \mathrm{~mm}$ (Perry, 1991; Farjon and Styles, 1997; López-Upton, 2002). P. pseudostrobus is known for its fast growth rates on good quality sites, straight trunk and high wood quality (López-Upton, 2002), all of which make this species among the best species candidate for tree breeding and extensive commercial plantations in México.

The native indigenous community from Nuevo San Juan Parangaricutiro (NSJP), at Michoacán, western México, is of the Purepecha ethnic group that practices sustainable forest management on approximately 11000 ha of pine forest. Their well-managed lands, owned under a community property status, contrast with the neighboring lands that have been largely deforested in this economically poor region known as Purépecha plateau (Sánchez-Pego, 1995; Jaffee, 1997). Forests tend to be dominated by P. pseudostrobus, which is distributed between 2200 to 2900 masl. Managers have applied harvest practices seed tree in mature stands followed by reforestation mostly with $P$. pseudostrobus seedlings produced in a local nursery. Also, abandoned agricultural fields are converted to $P$. pseudostrobus commercial forest plantations. Seedlings produced by the nursery were originated from cones collected within the community forest, but at present there are no recognized seed zones. Seedlings produced by the NSJP community are also extensively planted throughout the neighboring Purépecha plateau as part of governmental reforestation programs.

Studies along altitudinal gradients, mostly in the Rocky Mountains, USA, have shown that conifer populations tend to be differentiated genetically in response to differential selection pressures along altitudinal gradients. In general, populations originated from colder environments at higher altitudes, show lower growth potential, shorter periods of shoot elongation, and higher tolerance to freezing than populations originated from mild environments at low altitudes, which tend to have higher growth potentials, longer periods of shoot elongation and higher freezing damage (Campbell, 1979; Rehfeldt, 19881989 1991).

Unfortunately, forest tree populations soon will be decoupled of the climate for which they are adapted. Vegetation models suggest that by the end of the current century, suitable climates for the conifer forests in the Trans-Mexican Volcanic Belt could be reduced by $92 \%$ due to the ongoing climatic change (Rehfeldt et al., 2012). These changes should result from projected temperatures increasse by $3.7^{\circ} \mathrm{C}$ and precipitation decreased by $18.2 \%$ in the average, by the end of the century in México (Sáenz-Romero et al., 2010). If the climate to which $P$. psedostrobus populations are adapted shifts to higher altitudes, it is likely that current NSJP forests are going to exhibit a decline. Such decline or die-off of large masses of forest, apparently to causes related to climatic change, is underway in many parts of the world (Hogg et al., 2002; Breshears et al., 2005; Peñuelas et al., 2007; Worrall et al., 2008; Rehfeldt et al., 2009; Allen et al., 2010; Mátyás, 2010; Mátyás et al., 2010; Rehfeldt and Jaquish, 2010).

A previous study of Pinus pseudostrobus provenances from an altitudinal gradient in the NSJP region was tested in the field at two altitudinally contrasting sites, but produced inconclusive results. It showed a very weak pattern of altitudinal genetic differentiation among populations for seedling height, with populations from low altitude growing slightly more than those from higher altitudes. However, the relatively small size of the field tests, frost damage at the lower altitudinal field test site, and damage caused by gophers, undoubtedly decreased the statistical power so that genetic effects could not be detected (Viveros-Viveros et al., 2005).

The objectives of this research were: (a) To determine if an altitudinal pattern of genetic differentiation among $P$. pseudostrobus natural populations exists on NSJP forests; (b) To delimitate seed zones and establish seed and seedling movement guidelines if altitudinal patterns are detected; and (c) To predict the climate change impacts for the locations where present $P$. psedostrobus populations are currently distributed. 
In order to achieve objective (a), we devised two studies aimed at maximizing the expression of genetic differences among populations and estimating genetic by environment interactions by conducting two-year common-garden shadehouse tests at environmentally disparate locations in Morelia, Michoacán, México and Moscow, Idaho, USA. Objective (b) was aimed toward understanding the matching between genotypes and environment, and thereby to increase the survivorship and growth rate of $P$. pseudostrobus planted by the community. Objective (c) is directed toward finding management alternatives capable of maintaining adaptativeness in future environments.

\section{MATERIALS AND METHODS}

Wind-pollinated cones were collected from approximately eleven randomly selected trees from each of eight $P$. pseudostrobus natural populations distributed along an altitudinal gradient in the NSJP native indian community forest of Michoacán, at central-west México. Sampled populations were separated by an altitudinal interval of approximately $100 \mathrm{~m}$, from $2200 \mathrm{~m}\left(19^{\circ} 27.8^{\prime}\right.$ $\left.\mathrm{N}, 102^{\circ} 08.9^{\prime} \mathrm{W}\right)$ to $2910 \mathrm{~m}\left(19^{\circ} 28.4^{\prime} \mathrm{N}, 102^{\circ} 11.0^{\prime} \mathrm{W}\right.$. Note that revisiting the field sites prompted a correction in population altitude of $+100 \mathrm{~m}$ from those reported in Viveros-Viveros et al. (2005; 2006). Average geographic distance between contiguous populations was approximately $0.6 \mathrm{~km}$. Seeds from individual trees were mixed by population. The trees represented by these samples are termed populations while the location of a population is called the provenance.

For the Moscow test, seedlings were grown in SpencerLamaire $\odot 750 \mathrm{~cm}^{3}$ pots on a commercial substrate. Seeds were germinated inside a greenhouse where the seedlings remained until early summer in their first year. Then they were moved to a shadehouse (50\% shade) for the summer, and returned to the greenhouse for the winter; seedlings were subsequently moved back to the shadehouse in early March of the second year where they remained until growth ceased in the autumn. The experimental design was a randomized complete block design, with three blocks, eight provenances, and nine seedlings per plot. Seedlings were watered as needed. Total seedling height $(\mathrm{mm})$ was measured at two-week intervals during the second year, starting on April $3^{\text {rd }}$ before shoot elongation started and ending on October $1^{\text {st }}$ when shoot elongation had ceased.

For the Morelia test, seedlings were grown in $380 \mathrm{~cm}^{3}$ Broadway Plastics de México ${ }^{\circledR}$ pots on commercial substrate $\mathrm{Creciroot}^{\circledR}$ for one year. Then, seedlings were transplanted to a rectangular wooden-structure raised bed filled with a $40 \mathrm{~cm}$ layer of 4:1 mix of Creciroot ${ }^{\circledR}$ substrate and a local Andosol forest soil which was placed over a 20 $\mathrm{cm}$ layer of a extrusive volcanic small stones for improving drainage. The raised nursery bed was build inside a shadehouse (50\% shade). The experimental design was a randomized complete block, with three blocks, eight provenances and six seedlings in row plots within each block. Seedlings were spaced $13 \mathrm{~cm}$ within plots and 17 $\mathrm{cm}$ among plots. The first and the last plots were flanked by a protection row from randomly chosen seedlings. Seedlings were watered as needed, but little irrigation was required during the June-October rainy season.

Total seedling height $(\mathrm{mm})$ was measured weekly during the second year from January $8^{\text {th }}$ before shoot elongation started, to October $2^{\text {nd }}$ when growth had ceased, and seedlings were approximately 2 years of age. Measurements at both locations, therefore, were made during the second of two growing seasons. Seedlings at the Morelia test were harvested when they were two years-old; needles, branches, stem and roots were separated, dried for $62 \mathrm{~h}$ at $60^{\circ} \mathrm{C}$, and then weighed. Dry weights were also expressed as derived variables: shoot (shoot $=$ needles + branches + stem), shoot:root ratio, and total dry weight. Dry weight of seedlings growing at Moscow was not recorded.

A modified logistic growth function for total height was fit for each individual seedling on separate analysis for each location (Moscow and Morelia), using PROC NLIN of SAS (1999):

$Y_{i}=1 /\left(1+e^{(\beta 0+\beta 1 X+(\beta 2 / X))}\right)$

[Eqn. 1]

where $Y_{i}=$ observation on the $i^{\text {th }}$ seedling (total height); $\beta_{0}, \beta_{1}$ and $\beta_{2}$ are regression parameters; and $X=$ measurement date (Julian day).

Regression parameters $\left(\beta_{0}, \beta_{1}\right.$ and $\left.\beta_{2}\right)$ were used to estimate a growth curve of predicted values for each individual seedling, using the following model: 
$P_{i}=\left(1 /\left(1+e^{(\beta 0+\beta 1 X+\beta 2(1 / X))}\right)\right) \mathrm{Z}$

[Eqn. 2]

where $P_{i}=$ predicted growth (total height) for the $i^{\text {th }}$ seedling; $\beta_{0}, \beta_{1}$ and $\beta_{2}$ are regression parameters; $X=$ measurement date (Julian day); and $Z=$ total elongation $(\mathrm{mm})$.

Variables used in analyses of genetic variation include total elongation, the difference between the final measurement of two-year seedling height and the initial seedling height obtained at the beginning of the second year of growth. The regression models were used also for estimating the day during the second growing season on which $2 \mathrm{~mm}$ of growth had occurred, for each seedling, that is, the start of growth period in Julian days; the day on which all but $2 \mathrm{~mm}$ of growth had occurred, that is, the end or cessation of growth period in Julian days; the rate of elongation between $20 \%$ and $80 \%$ of total elongation, that is, the maximum growth rate; and the number of days between start of growth and end of growth, the duration of growth.

These variables were used in an analysis of variance to test significance among populations, using PROC GLM of SAS (SAS Institute, 1999). Ratio of variance component to total variance was estimated using PROC VARCOMP METHOD = REML (SAS Institute, 1999). These analyses used the following statistical model:

$Y_{i j k l}=\mu+L_{i}+B_{j}\left(L_{i}\right)+P_{k}+L_{i}^{*} P_{k}+P_{k}^{*} B_{j}\left(L_{i}\right)+\varepsilon_{i j k l}$

[Eqn. 3]

where $Y_{i j k l}=$ observation on the $l^{\text {th }}$ seedling of the $k^{\text {th }}$ population of the $j^{\text {th }}$ block in the $i^{\text {th }}$ location, $\mu=$ overall mean, $L_{i}=$ effect of the $i^{\text {th }}$ location, $B_{j}\left(L_{i}\right)=$ effect of $j^{\text {th }}$ block nested in the $i^{\text {th }}$ location, $P_{k}$ effect of the $k^{\text {th }}$ population, $L_{i} x P_{j}=$ interaction of location by population, $\mathrm{P}_{k}{ }^{{ }^{X}} \mathrm{~B}_{j}\left(\mathrm{~L}_{\mathrm{i}}\right)=$ interaction of population by block nested in location, and $\varepsilon_{i j k l}=$ error term; $i=1, \ldots . s, j=1, \ldots . b$, and $k=1, \ldots . t$, and $l=1, \ldots n$, where $s=2, b=3, t=8, n=9$ in Moscow test and $n=6$ in Morelia test, which are the number of locations, blocks, populations, and seedlingsper-plot, respectively.

In addition, separate analyses were conducted for variables measured at each location, including the dry weights of seedlings grown at Morelia, with the following model:
$\mathrm{Y}_{i j k}=\mu+\mathrm{B}_{i}+\mathrm{P}_{j}+\mathrm{B}_{i}{ }^{*} \mathrm{P}_{j}+\varepsilon_{i j k} \quad$ [Eqn. 4] where $Y_{i j k}=$ observation on the $k^{\text {th }}$ seedling of the $j^{\text {th }}$ population of the $i^{\text {th }}$ block, $\mu=$ overall mean, $B_{i}=$ effect of $i^{\text {th }}$ block nested, $P_{j}$ effect of the $j^{\text {th }}$ population, $\mathrm{B}_{i}{ }^{\mathrm{x}} \mathrm{P}_{j}=$ interaction of population by block, and $\varepsilon_{i j k}=$ error term.

The relationship between the altitude of the seed source and genetic variation among populations for those variables for which population effects were significant was assessed with linear and quadratic models, using PROC REG (SAS, 1999). The linear model was:

$\mathrm{Y}_{i j}=\beta_{0}+\beta_{1} \mathrm{X}_{i}+\varepsilon_{i j}$

[Eqn. 5]

and the quadratic model was:

$\mathrm{Y}_{i j}=\beta_{0}+\beta_{1} \mathrm{X}_{i}+\beta_{2} \mathrm{X}_{i}^{2}+\varepsilon_{i j}$

[Eqn. 6]

where $Y_{i j}=$ population mean, $\beta_{0}=$ intercept, $\beta_{1}$ and $\beta_{2}=$ regression parameters, $X_{i}=$ altitude $(\mathrm{m})$ of $i^{\text {th }}$ population origin, $\varepsilon_{i j}=$ error term.

\section{Seed zoning}

Differentiation along the cline was interpreted relative to the least significant difference (LSD, $\alpha=0.20$ ) in altitude that must separate populations before one can be reasonably certain of genetic differentiation (Rehfeldt, 1991; Sáenz-Romero et al., 2006). Provisional altitudinal seed zones were delimitated using LSD.

\section{Estimation of climatic variables}

Mean annual temperature, annual precipitation, annual degree days $\left(>5^{\circ} \mathrm{C}\right.$ ), an annual aridity index (ratio of square root of annual degree days to annual precipitation), and several additional climate variables were estimated for a total of eight Pinus pseudostrobus localities for contemporary climate $(1961$ - 1990). Climate estimations were obtained from spline climate surfaces fitted from monthly average temperatures (mean, maximum and minimum) and monthly precipitations from numerous weather stations (Sáenz-Romero et al., 2010).

Forecasted climate change estimates for the provenances for the decade centered in year 2030, were 
obtained after refitting the spline climate surfaces with outputs of one global circulation model (Canadian Center for Climate Modeling and Analysis, CCCMA), and one emission scenario A2 (see details in Sáenz-Romero et al., 2010). Point estimates for each provenance were obtained by interrogating the spline climatic surfaces (contemporary and year 2030) by using a web-based interface (Crookston, 2010).

Climatic clines in genetic variation among populations were assessed with regression models using PROC REG (SAS Institute, 1999) of genetic responses of populations on provenance climate variables. The clines were examined in the context of the seed and seedling transfers required for realigning genotypes and climate for the year 2030 .

\section{RESULTS AND DISCUSSION}

\section{Differences among test locations}

Analyses of variance detected significant statistical differences between locations $(P \leq 0.01)$ for the start, end, duration and amount of shoot elongation. Final height was significant at $\mathrm{P}=0.0527$ level, although there was no significant difference between locations for growth rate (Table 1). Also, there were no significant genotype by environment interactions (Location $\mathrm{x}$ Provenance).

In comparison to provenances growing at Moscow, those at Morelia showed a higher total elongation (412 $\mathrm{mm} v$ s. 308), an earlier start date (day 47 vs. day 113), earlier ending date (day $227 v s$. day 250), longer duration of shoot growth (181 days vs. 138) and larger final height (571 mm vs. 512) (Figure 1). Similar result were found for 6-month-old seedlings of Pinus patula provenances, also originated from an altitudinal gradient and growing in nursery conditions in contrasting localities (SáenzRomero et al., 2011). The best growth occurred at the locality providing the best environmental conditions, and all populations responded similarly to the favorable conditions so that there were no detectable interactions of genotype by environment.

\section{Differences among populations}

When analyses used data from both sites simultaneously, differences among populations were not significant for any seedlings trait related to seedling growth in height (start, end, duration, rate and amount of elongation and final height), as shown in Table 1. However, when the analyses were conducted separately for each location, significant differences were detected among populations in the Moscow test for the ending date and duration of elongation and for final height. Differences for total elongation also were significant at $\mathrm{P}=$ 0.076 (Table 1). In contrast, at Morelia, no significant differences among populations were detected for all traits related to shoot growth (Table 1). Similar results were found for the same provenances of the same age growing in field conditions at two localities: since some traits showed significant differences among provenances in one field location and not on the other, while differences in other traits could not be detected at either location (Viveros-Viveros et al., 2005).

Dry weight traits at the Morelia test, however, showed large differences among populations for needle, shoot and total dry weight $(\mathrm{P}<0.025)$, while differences for stem dry weight were significant at $\mathrm{P}=0.055$. No significant differences were detected for dry weight of branches and roots or for the shoot:root ratio dry weight (Table 2).

\section{Altitudinal pattern of genetic differentiation}

Population means for traits measured at Moscow and shown by ANOVA to be, significant were poorly related to provenance altitude. The best fitting regressions were obtained with the quadratic model, but the regressions were not statistically significant, for the three traits: end of growth $\left(\mathrm{R}^{2}=0.49, \mathrm{P}=0.182\right)$, duration of growth $\left(\mathrm{R}^{2}=\right.$ $0.28, \mathrm{P}=0.436)$, and seedling height $\left(\mathrm{R}^{2}=0.10, \mathrm{P}=0.761\right)$. A factor contributing to this poor fit of the regression model was that the population originated at $2600 \mathrm{~m}$ had an atypical low mean value expected for its altitude (Figure 2). Thus, in general, populations from middle altitudes achieved a better growth through a longer duration of shoot elongation (scatter plot not shown, but mirrors that of Figure 2), while populations from the extreme low and high altitudinal limits showed less growth. The same trend was found for 6-month-old seedlings from $P$. patula provenances: mid-altitude provenances had better growth than provenances from both extremes of altitudinal distribution, and the quadratic regression model was not significant either (Sáenz-Romero, et al., 2011). 
In contrast, a clear altitudinal pattern was revealed for dry weight traits, with populations from lower altitudes having larger dry weights than populations from higher altitudes (Figure 3). The fit of regression models of population average dry weight on provenance altitude for dry weight traits were highly significant for both linear regression and quadratic models. The fit of the linear regression models were, needle dry weight $\left(\mathrm{R}^{2}=0.75, \mathrm{P}=\right.$ $0.005)$, stem dry weight $\left(R^{2}=0.69, P=0.011\right)$, total dry weight $\left(R^{2}=0.80, P=0.003\right)$, and shoot dry weight $\left(R^{2}=\right.$ $0.72, \mathrm{P}=0.007)$. Figure 3 shows the behavior of total dry weight; the scattering of data points was similar for needle, stem and aerial dry weight. This pattern of altitudinal genetic variation is similar to that found for $P$. oocarpa (Sáenz-Romero et al., 2006) and for P. hartwegii (ViverosViveros et al., 2009) in Mexican mountains.

Table 1. Two-location and by each location analysis of variance for two-year-old Pinus pseudostrobus provenance test. Percent of contribution to total variance $(\%)$ and significance values $(P)$.

\begin{tabular}{|c|c|c|c|c|c|c|c|c|c|c|c|c|c|}
\hline \multirow[t]{2}{*}{ S.V. } & \multirow[t]{2}{*}{ d.f. } & \multicolumn{2}{|c|}{ Elongation } & \multicolumn{2}{|c|}{ Start } & \multicolumn{2}{|c|}{ End } & \multicolumn{2}{|c|}{ Duration } & \multicolumn{2}{|c|}{ Rate } & \multicolumn{2}{|c|}{ Height } \\
\hline & & $\%$ & $\mathrm{P}$ & $\%$ & $\mathrm{P}$ & $\%$ & $\mathrm{P}$ & $\%$ & $\mathrm{P}$ & $\%$ & $\mathrm{P}$ & $\%$ & $\mathrm{P}$ \\
\hline & \multicolumn{13}{|c|}{ Two- location analysis } \\
\hline Block(L) & 4 & 1.3 & .1933 & 0.0 & .2669 & 0.0 & .8082 & 0.0 & .7344 & 0.0 & .7637 & 0.0 & .8384 \\
\hline Provenance & 7 & 0.0 & .7401 & 0.0 & .5673 & 0.0 & .8833 & 0.0 & .8826 & 2.2 & .0963 & 1.5 & .3790 \\
\hline $\mathrm{LxP}$ & 7 & 1.9 & .1513 & 0.0 & .4958 & 1.5 & .0998 & 0.3 & .1357 & 0.0 & .7230 & 3.8 & .2557 \\
\hline \multirow[t]{2}{*}{ Error } & $\dagger$ & 63.2 & & 4.0 & & 70.6 & & 46.0 & & 70.2 & & 83.3 & \\
\hline & \multicolumn{13}{|c|}{ Moscow, Idaho, USA } \\
\hline Block & 2 & 0.0 & .5125 & 0.2 & .2139 & 0.0 & .9105 & 0.0 & .5138 & 0.0 & .6282 & 0.0 & .4302 \\
\hline Provenance & 7 & 7.7 & .0760 & 0.0 & .5267 & 8.1 & .0072 & 4.1 & .0467 & 0.0 & .5573 & 13.7 & .0119 \\
\hline BloxProv & 14 & 5.4 & .0699 & 0.0 & .6674 & 0.0 & .7535 & 0.0 & .7043 & 10.3 & .0085 & 3.1 & .1535 \\
\hline Provenance & 7 & 0.0 & .5666 & 0.0 & .5458 & 0.0 & .6145 & 0.0 & .6356 & 4.8 & .2515 & 0.0 & .7553 \\
\hline BloxProv & 13 & 0.0 & .5862 & 0.0 & .8436 & 0.0 & .5434 & 0.0 & .6860 & 0.0 & .4582 & 0.0 & .4218 \\
\hline Error & $\dagger$ & 97.5 & & 100 & & 100 & & 100 & & 95.2 & & 95.2 & \\
\hline
\end{tabular}

Error degrees of freedom are: ${ }^{\dagger} 278$ for elongation and start, and 275 for end, duration, rate and height; ${ }^{\dagger \dagger} 93$ for elongation and start and 90 for end, duration, rate and height. S.V. = source of variation; d.f. = degrees of freedom.

Table 2. Analysis of variance for dry weight traits for two-year-old Pinus pseudostrobus provenances tested at Morelia, Michoacán, México. Percent of contribution to total variance (\%) and significance values (P).

\begin{tabular}{|c|c|c|c|c|c|c|c|c|c|c|c|c|c|c|c|}
\hline \multirow[t]{2}{*}{ S.V. } & \multirow[t]{2}{*}{ d.f. } & \multicolumn{2}{|c|}{ Needles } & \multicolumn{2}{|c|}{ Branches } & \multicolumn{2}{|c|}{ Stem } & \multicolumn{2}{|c|}{ Root } & \multicolumn{2}{|c|}{ Total } & \multicolumn{2}{|c|}{ Aerial } & \multicolumn{2}{|c|}{ Aerial/Root } \\
\hline & & $\%$ & $\mathrm{P}$ & $\%$ & $\mathrm{P}$ & $\%$ & $\mathrm{P}$ & $\%$ & $\mathrm{P}$ & $\%$ & $\mathrm{P}$ & $\%$ & $\mathrm{P}$ & $\%$ & $\mathrm{P}$ \\
\hline Block & 2 & 0.00 & .3704 & 0.00 & .7428 & 2.92 & .0797 & 0.00 & .5989 & 0.10 & .1552 & 0.65 & .1245 & 1.00 & .5162 \\
\hline Provenance & 7 & 3.96 & .0194 & 0.24 & .2114 & 6.60 & .0545 & 0.32 & .1561 & 4.87 & .0225 & 6.61 & .0141 & 0.00 & .5390 \\
\hline BloxProv & 13 & 0.00 & .9621 & 0.00 & .8180 & 0.00 & .6881 & 0.00 & .8444 & 0.00 & .9255 & 0.00 & .9166 & 7.57 & .1257 \\
\hline rror & 105 & 96.04 & & 99.76 & & 90.47 & & 99.68 & & 95.03 & & 92.74 & & 91.43 & \\
\hline
\end{tabular}

S.V. = source of variation; d.f. $=$ degrees of freedom. 


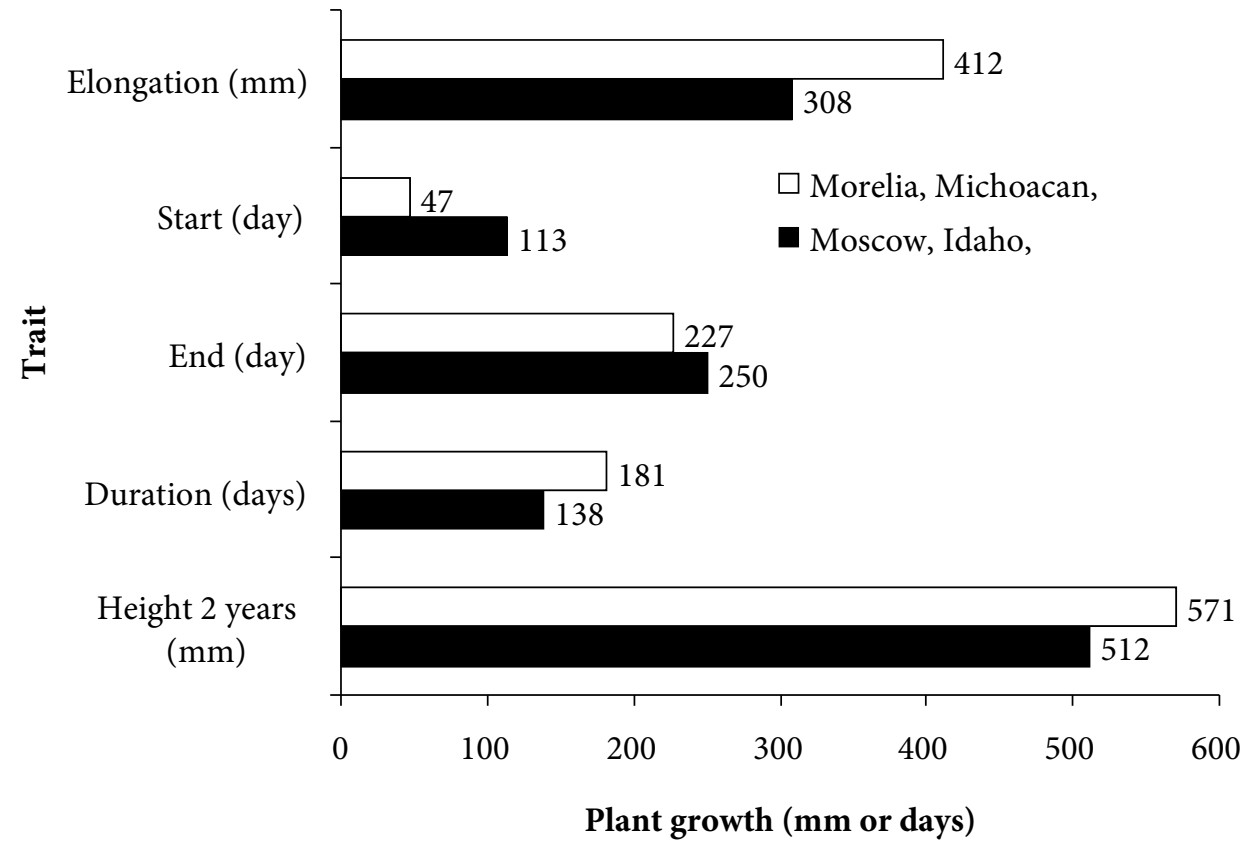

Figure 1. Average by location of elongation, date of growth start (Julian day), date of growth end (Julian day), duration of shoot growth and final height (twoyear-old) for a Pinus pseudostrobus provenance test.

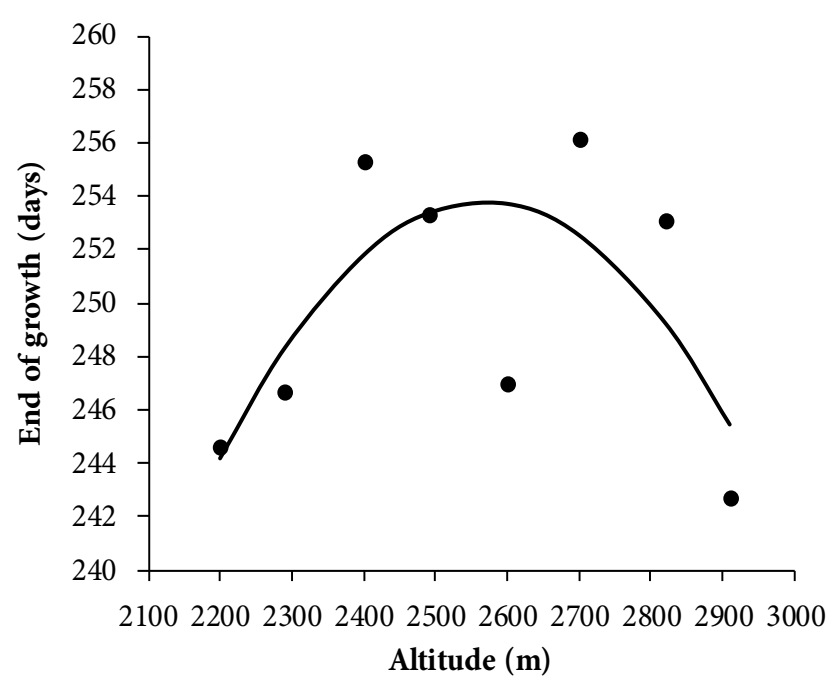

Figure 2. Population averages for end of growth from Moscow test fitted against provenance altitude, using a quadratic regression model $\left(R^{2}=0.49, P=0.182\right)$.

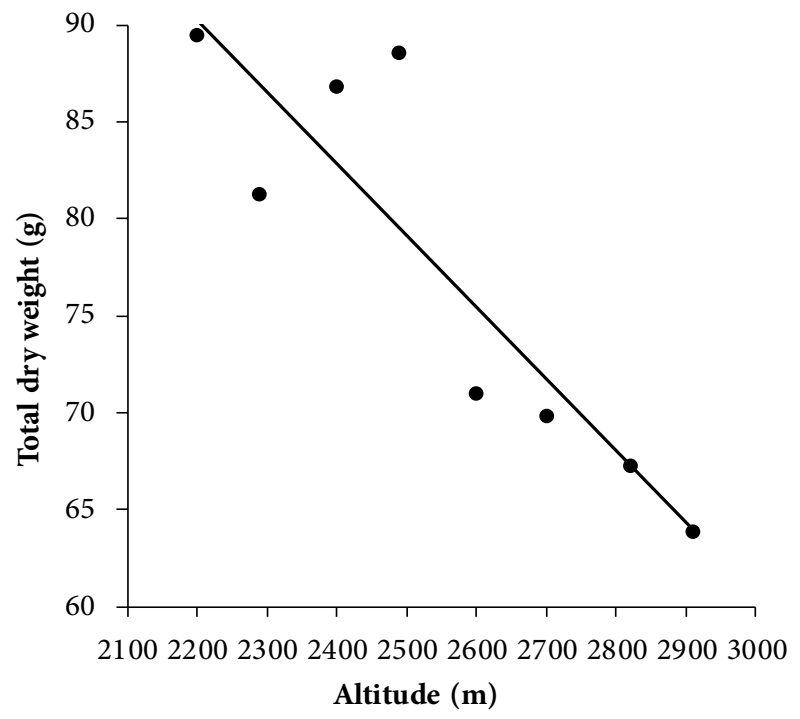

Figure 3. Population averages for total dry weight from Morelia test fitted against provenance altitude, using a linear regression model $\left(R^{2}=0.80, P=0.003\right)$. 


\section{Seed zoning and guidelines for seed movement}

The least significant difference (LSD, $\alpha=0.20$ ) between two populations was $10.93 \mathrm{~g}$ for total dry weight. The ratio of LSD to the regression coefficient of population means on altitude of the seed source suggests that populations separated by $296 \mathrm{~m}$ are likely to be genetically different. Considering that the maximum altitudinal interval of the natural distribution of $P$. pseudostrobus in the region of study is $700 \mathrm{~m}$, that is, from 2200 to $2900 \mathrm{~m}$, three seed zones would cover the entire natural distribution. Thus, we used a $300 \mathrm{~m}$ of altitudinal difference to design seed zones for P. pseudostrobus in the NSJP, Michoacán region (Table 3), with delimitation beginning at an altitude of 2100 . Notice than an equivalent criteria would be an altitudinal interval of $\pm 150 \mathrm{~m}$ from a specific seed source.

Suitable guidelines for reforestation of ecological restoration could be: (a) Reforestation of a given seed zone using seedlings originating from the same seed zone, or alternatively, (b) Reforest a site at a given altitude using seedlings originating from seed collected from $\pm 150 \mathrm{~m}$ in altitude from the site to be reforested.

For tree breeding and for establishing commercial plantations in a particular seed zone, the guideline is to use seeds of the best growing provenance or families within the seed Zone with the provenances with best performance. Among seed zones, Zone II (Table 3) contains the populations with highest growth potential, most particularly which originated at $2500 \mathrm{~m}$ (Figure 3). The provenance from $2200 \mathrm{~m}$ had also a high mean dry weight (Figure 3), but it had a low performance in seedling height. The field performance of the $2500 \mathrm{~m}$ provenance (Zone II) was also superior among three provenances from NSJP and among several other provenances from Michoacán. That provenance is from Cerro de Tumbiscatillo, and it was incorrectly recorded in altitude as $2400 \mathrm{~m}$ by Viveros-Viveros et al. $(2005 ; 2006)$.

\section{Climatic zoning}

Seed zone limits can be translated to contemporary climates by means of the strong association (indicated by a regression analysis) between total dry weight and two temperature variables that parallel our altitudinal gradient: mean annual temperature $\left(\mathrm{R}^{2}=0.81, \mathrm{P}=0.002\right)$ and growing degree days $\left(\mathrm{R}^{2}=0.81, \mathrm{P}=0.002\right)$. However, association of total dry weight with precipitation is not significant $\left(\mathrm{R}^{2}=0.11, \mathrm{P}=0.427\right)$, largely because our estimates of precipitation for this region show that it is relatively constant across the altitudinal gradient. Annual aridity index is significant $\left(\mathrm{R}^{2}=0.68, \mathrm{P}=0.012\right)$, apparently as result of the strong altitudinal cline of growing degree days. Seed zone delineation based on temperature variables followed the same procedure used above for elevation. Additionally, we estimated the association between elevation and mean annual temperature $\left(\mathrm{R}^{2}=0.99, \mathrm{P}<0.001\right)$ and growing degree days $\left(\mathrm{R}^{2}=0.99, \mathrm{P}<0.001\right)$ in order to relate altitudinal seed zoning with the climatic seed zones (Table 3 ).

Our practical guidelines for designing seed zones should be viewed as provisional. Future research needs to be done on the correlation between dry weight at young trees and traits of economic importance at later ages. Nonetheless, the practical use of the current results for the studied region is highly recommended, largely because there are not guidelines for this species in México.

\section{Climatic change predictions and assisted migration strategies}

Guidelines for adaping forest management to climatic change, that is, goals aimed toward assuring that in 2030 genotypes will occupy climates similar to those they inhabit today, must accommodate considerable uncertainty. It is well known that temperatures decrease as altitudes increase according to well established lapse rates. Genetic responses parallel this trend (Figure 4, solid markers). For the seed zones of Table 3, zones differ by about $0.88{ }^{\circ} \mathrm{C}$ in mean annual temperature and about 320 degree-days $>5^{\circ} \mathrm{C}$. Our estimates for 2030 show mean annual temperature to increase by about $1.6^{\circ} \mathrm{C}$ and for degree-days to increase by about 565 . This means that the climates now inhabited by the $P$. pseudstrobus populations tested in this study should occur in 2030 at approximately $535 \mathrm{~m}$ of higher altitude than they occur today. Because the climate may continue to warm, we recommend today the transfer of seeds about $300 \mathrm{~m}$, that is, from a lower seed zone to a higher.

This strategy for accommodating the changing climate would be a temporary guideline for assisting the migration of $P$. pseudostrobus while maintaining adaptation to 
changing temperatures (Sáenz-Romero et al., 2010). More information is needed on responses of $P$. pseudostrobus to climate and on the impacts of climate to contemporary forests before concrete guidelines can be formulated.

In regard to climate change, it is also noteworthy that the climate is projected to decline by about $170 \mathrm{~mm}$ by 2030 across this region. A decline in precipitation coupled with increasing temperatures means that the climate will become more and more arid. Our calculations of the annual aridity index, a ratio of degree-days $>5{ }^{\circ} \mathrm{C}$ to annual precipitation, show that the index should increase but yet remain well within the limits inhabited by $P$. pseudostrobus today. Nonetheless, an increase in aridity will undoubtedly mean that forests will be of lesser density and anticipated growth rates may not be achieved.

A more rigorous analysis of global warming impacts is needed to articulate management strategies. To find a more detailed solution might require modeling the suitable habitat for contemporary and for future climatic conditions, as it was done using the Random Forest Analysis for P. chiapensis (Sáenz-Romero et al., 2010). However, such an approach would require a more sophisticated analysis than ours. In the meantime, we suggest to move middle and upper provenances upwards $300 \mathrm{~m}$, the maximum width of a seed zone. To transfer them beyond the maximum width of a seed zone in anticipation of the warming expected after 2030, would increase the risk of frost damage in contemporary times (Viveros-Viveros et al., 2007; Sáenz-Romero and TapiaOlivares, 2008).

\section{CONCLUSIONS}

Statistical analyses detected significant genetic differentiation among $P$. psedostrobus populations, with a strong altitudinal cline by which seedlings originating from populations at low altitudes had larger biomass values than populations from higher altitudes. Populations separated by about $295 \mathrm{~m}$ of altitudinal are expected to differ genetically. Thus, we suggest three altitudinal seed zones (Zone I: $2100 \mathrm{~m}$ to $2400 \mathrm{~m}$; Zone II: $2400 \mathrm{~m}$ to $2700 \mathrm{~m}$; Zone III: $2700 \mathrm{~m}$ to $3000 \mathrm{~m}$ ) that can be translated to climatic zones delimited by mean annual temperatures (Zone I: 15.50 to $14.62{ }^{\circ} \mathrm{C}$; II: 14.62 to $13.75{ }^{\circ} \mathrm{C}$; III: 13.75 to $12.87^{\circ} \mathrm{C}$ ) or by degree days $>5^{\circ} \mathrm{C}$ (Zone I: 3822 to 3506; II: 3506 to 3189; III: 3189 to 2872). As a general response to climatic change, we suggest to implement assisted migration altitudinally upwards (300 $\mathrm{m})$ as a measure to maintain population adaptation by realigning genotypes to future climates.

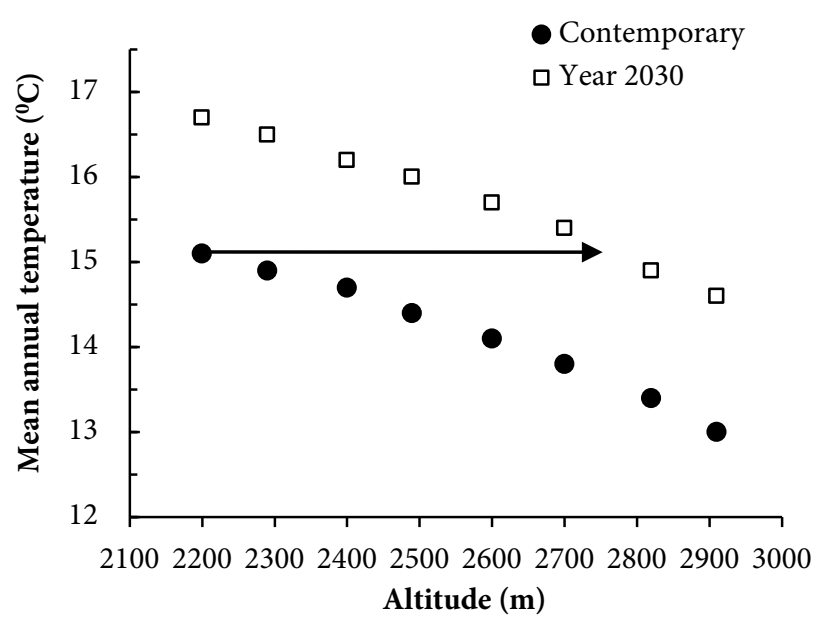

Figure 4. Provenance mean annual temperature of contemporary and year 2030 climate plotted against provenance altitude. Arrow indicates altitudinal upward movement needed to match a temperature for which a population is adapted at present, that will occur at higher elevation in year 2030.

Table 3. Simplified limits, ranges and intervals of three Pinus pseudostrobus seed zones, based on intervals of altitude, mean annual temperature and degree days $>5^{\circ} \mathrm{C}$ of contemporary climate.

\begin{tabular}{|c|c|c|c|c|c|c|c|c|c|c|c|c|}
\hline \multirow[t]{2}{*}{ Seed zone } & \multicolumn{4}{|c|}{ Altitude (m) } & \multicolumn{4}{|c|}{ Mean annual temperature $\left({ }^{\circ} \mathrm{C}\right)$} & \multicolumn{4}{|c|}{ Degree days $>5^{\circ} \mathrm{C}$} \\
\hline & \multicolumn{2}{|c|}{ Limits (m) } & Range & $\begin{array}{c}\text { Interval } \\
( \pm)\end{array}$ & \multicolumn{2}{|c|}{ Limits $\left({ }^{\circ} \mathrm{C}\right)$} & Range & $\begin{array}{c}\text { Interval } \\
( \pm)\end{array}$ & \multicolumn{2}{|c|}{ Limits } & Range & $\begin{array}{c}\text { Interval } \\
( \pm)\end{array}$ \\
\hline 1 & 2100 & 2400 & 300 & 150 & 15.50 & 14.62 & 0.88 & 0.44 & 3822 & 3506 & 317 & 158.5 \\
\hline 2 & 2400 & 2700 & 300 & 150 & 14.62 & 13.75 & 0.88 & 0.44 & 3506 & 3189 & 317 & 158.5 \\
\hline
\end{tabular}




\section{ACKNOLEDGEMENTS}

Funding was provided to CSR by Mexican Council of Science and Technology and the Mexican National Forestry Commission (CONACYT-SIMORELOS-20000306021 and CONACYT-CONAFOR-2002-C01-4655), the State of Michoacán (CONACYT-MICHOACÁN2009-127128), the Coordinación de la Investigación Científica of the Universidad Michoacana de San Nicolás de Hidalgo (5.1) and the USDA- Forest Service, Rocky Mountain Research Station (01-JV-11222063-183). Thanks to Manuel Echeverría, Rafael Echeverría, Luis Toral, Felipe Aguilar and other persons from the Forestry Office of the native indian community of Nuevo San Juan Parangaricutiro, Michoacán, and to Ernesto Moreno, Daniel Saldívar, Víctor Quiñonez and other personnel of the Michoacán State Forest Commission for their help with seed collection. We thank Patrick Wells at Moscow and Soraya González and Guadalupe Hernández at Morelia for their help for experiments maintenance, and to Hans Nienstaedt for valuable comments.

\section{REFERENCES}

Allen C D, A K Macalady, H Chenchouni, D Bachelet, N McDowell, M Vennetier, T Kitzberger, A Rigling, D D Breshears, E H Hogg, P Gonzalez, R Fensham, Z Zhangm, J Castro, N Demidova, J H Lim, G Allard, S W Running, A Semerci, N Cobb (2010) A global overview of drought and heat-induced tree mortality reveals emerging climate change risks for forests. For. Ecol. Manage. 259:660-684.

Breshears D D, N S Cobb, P M Rich, K P Price, C D Allen, R G Balice, W H Romme, J H Kastens, M L Floyd, J Belnap, J J Anderson, O B Myers, C W Meyer (2005) Regional vegetation die-off in response to global-change-type drought. Proc. Nat. Acad. Sci. 102: 15144-15148.

Campbell R K (1979) Genecology of Douglas-fir in a watershed in the Oregon Cascades. Ecology 60:1036-1050.

Crookston N L (2010) Custom Data Requests. In: Current and Future Climate Estimates, Plant-Climate Relationships, and Potential Impacts of Global Warming Scenarios in Western North America and Mexico. Available at: http://forest.moscowfsl.wsu.edu/climate/. Moscow Forestry Sciences Laboratory, Rocky Mountain Research Station, USDA Forest Service. (February 2010).

Farjon A, B T Styles (1997) Pinus (Pinaceae). Flora Neotropica Monograph 75. New York Botanical Garden, New York, USA. $291 \mathrm{p}$.

Hogg E H, J P Brandt, B Kochtubajda (2002) Growth and dieback of aspen forests in northwestern Alberta, Canada, in relation to climate and insects. Can. J. For. Res. 32:823-832.
Jaffee D (1997) Restoration where people matter; reversing forest degradation in Michoacán, México. Restor. Manage. Notes 15:147-155.

López-Upton J (2002) Pinus pseudostrobus Lindl. In: Tropical Tree Seed Manual. J A Vozzo (ed). USDA Forest Service. Pp: 636-638.

Mátyás C (2010) Forecasts needed for retreating forests. Nature 464:1271.

Mátyás C, I Berki, B Czúcz, B Gálos, N Móricz, E Rasztovits (2010) Future of beech in Southern Europe from the perspective of evolutionary ecology. Acta Silv. Lignaria Hungarica 6:91-110.

Peñuelas J, R Oyaga, M Boada, A S Jump (2007) Migration, invasion and decline: changes in recruitment and forest structure in a warming-linked shift of European beech forest in Catalonia (NE Spain). Ecography 30: 830-838.

Perry J P (1991) The Pines of México and Central America. Timber Press, Portland Oregon, USA, $231 \mathrm{p}$.

Rehfeldt G E (1988) Ecological genetics of Pinus contorta from the Rocky Mountains (USA): a synthesis. Silvae Genet. 37:131-135.

Rehfeldt G E (1989) Ecological adaptations in Douglas-fir (Pseudotsuga menziesii var. glauca): a synthesis. For. Ecol. Manage. 28:203215.

Rehfeldt G E (1991) A model of genetic variation for Pinus ponderosa in the Inland Northwest (U.S.A.): applications in gene resource management. Can. J. For. Res. 21: 1491-1500.

Rehfeldt G E, D E Ferguson, N L Crookston (2009) Aspen, climate, and sudden decline in western USA. For. Ecol. Manage. 258:23532364.

Rehfeldt G E, B C Jaquish (2010) Ecological impacts and management strategies for western larch in the face of climate-change. Mitig. Adapt. Strategies Global Change 15:283-306.

Rehfeldt G E, N L Crookston, C Sáenz-Romero, E Campbell (2012) North American vegetation model for land-use planning in a changing climate: a solution to large classification problems. Ecol. Applica. 22:119-141.

Sáenz-Romero C, R Guzmán-Reyna, G E Rehfeldt (2006) Altitudinal genetic variation among Pinus oocarpa populations in Michoacán, México; implications for seed zoning, conservation of forest genetic resources, tree breeding and global warming. For. Ecol. Manage. 229:340-350.

Sáenz-Romero C, B L Tapia-Olivares (2008) Genetic variation in frost damage and seed zone delineation within an altitudinal transect of Pinus devoniana (P. michoacana) in Mexico. Silvae Genet. 57:165-170.

Sáenz-Romero C, G E Rehfeldt, N L Crookston, P Duval, R St-Amant, J Beaulieu, B A Richardson (2010) Spline models of contemporary, 2030, 2060 and 2090 climates for México and their use in understanding climate-change impacts on the vegetation. Climatic Change 102:595-623.

Sáenz-Romero C, L F Ruiz-Talonia, J Beaulieu, N M Sánchez-Vargas, G E Rehfeldt, (2011) Genetic variation among Pinus patula populations along an altitudinal gradient. Two environment nursery tests. Rev. Fitotec. Mex. 34:19-25.

Sánchez-Pego M A (1995) The forestry enterprise of the indigenous community of Nuevo San Juan Parangaricutiro, Michoacán, México. In: Proc. Symposium Forestry in the Americas: Community Based Management and Sustainability. Institute for Environmental Studies and Land Tenure Center, University of 
Wisconsin-Madison. 3-4 February 1995, Madison, Wisconsin, USA. pp: 173-196.

SAS Institute Inc. (1999) SAS/STAT Computer Software. Release 8. SAS Institute Inc., North Carolina, USA. 3809 p.

Viveros-Viveros H, C Sáenz-Romero, J López-Upton, J J VargasHernández (2005) Variación genética altitudinal en el crecimiento de plantas de Pinus pseudostrobus Lindl. en campo. Agrociencia 39:575-587.

Viveros-Viveros H, C Sáenz-Romero, J J Vargas-Hernández, J LópezUpton (2006) Variación entre procedencias de Pinus pseudostrobus establecidas en dos sitios en Michoacán, México. Rev. Fitotec. Mex. 29:121-126.
Viveros-Viveros H, C Sáenz-Romero, J López-Upton, J J VargasHernández (2007) Growth and frost damage variation among Pinus pseudostrobus, P. montezumae and P. hartwegii tested in Michoacán, México. For. Ecol. Manage. 253:81-88.

Viveros-Viveros H, C Sáenz-Romero, J J Vargas-Hernández, J LópezUpton, G Ramírez-Valverde, A Santacruz-Varela (2009) Altitudinal genetic variation in Pinus hartwegii Lindl. I.: height growth, shoot phenology, and frost damage in seedlings. For. Ecol. Manage. 257:836-842.

Worrall JJ, L Egeland, T Eager, R A Mask, E W Johnson, P A Kemp, W D Shepperd (2008) Rapid mortality of Populus tremuloides in southwestern Colorado, USA. For. Ecol. Manage. 255: 686-696. 

